\title{
Picoplankton community structure in the subarctic Pacific Ocean and the Bering Sea during summer 1999
}

\author{
Hongbin Liu ${ }^{1, *}$, Koji Suzuki $^{1}$, Chie Minami ${ }^{1}$, Toshiro Saino ${ }^{1}$, Masataka Watanabe $^{2}$ \\ ${ }^{1}$ Institute for Hydrospheric and Atmospheric Sciences, Nagoya University, Chikusa-ku, Nagoya 464-8601, Japan \\ ${ }^{2}$ National Institute for Environmental Studies, 16-2 Onogawa, Tsukuba-Shi, Ibaraki 305-0053, Japan
}

\begin{abstract}
We studied picoplankton community structures in the subarctic Pacific Ocean and the Bering Sea during summer 1999 using flow cytometric analysis. The picoplankton community in the studied area was comprised of Synechococcus spp., eukaryotic ultraplankton and heterotrophic bacteria. Prochlorococcus spp. were not detected at any station. Abundances of Synechococcus and eukaryotic ultraplankton were at approximately the same level of $10^{3}$ to $10^{4}$ cells ml ${ }^{-1}$ within the upper euphotic layer in the subarctic gyres. An abundance of Synechococcus spp. higher than $5 \times$ $10^{4}$ cells ml ${ }^{-1}$ was found at the surface to $40 \mathrm{~m}$ depth in the northern Gulf of Alaska, whereas low Synechococcus spp. abundance (about $500 \mathrm{cells} \mathrm{m}^{-1}$ ) was found in the upper euphotic layer in the Bering Sea. Abundances of heterotrophic bacteria were about 2 orders of magnitude higher than those of Synechococcus spp. and eukaryotic ultraplankton, with higher abundance generally occurring in the area of high autotrophic biomass. Although Synechococcus spp. and eukaryotic ultraplankton occurred at comparable abundance, the latter contributed significantly more to photosynthetic carbon biomass, except in the northern Gulf of Alaska, where the biomass of Synechococcus spp. and eukaryotic ultraplankton were approximately equal. Cellular red fluorescence for Synechococcus spp. and eukaryotic ultraplankton increased by an average 4- and 2-fold, respectively, from the surface to the bottom of the euphotic layer, with the smallest increase occurring in the Bering Sea. Both the red fluorescence and forward light scatter (FSC, related mainly to cell size) per cell varied more than 2-fold spatially, with the highest value occurring in the Bering Sea. These variations were probably caused by differences in physiological conditions and species compositions. Overall, picophytoplankton was the dominant contributor to total autotrophic biomass in the subarctic North Pacific, but contributed only a small fraction to total autotrophic biomass in the Bering Sea. The Western Gyre (WG) and the Alaskan Gyre (AG) possess both similarities and differences in biogeochemical processes and microbial food-web dynamics. The slightly higher phytoplankton biomass, photosynthetic efficiencies and growth rates in WG than AG suggests less severe iron limitation in the WG.
\end{abstract}

KEY WORDS: Picoplankton · Community structure - Flow cytometry · Heterotrophic bacteria • Subarctic Pacific Ocean · Bering Sea

\section{INTRODUCTION}

The picophytoplankton $(<2 \mu \mathrm{m})$ is composed of 3 groups, including the cyanoba cteria Prochlorococcus

${ }^{*}$ Present address: Louisiana Universities Marine Consortium, 8124 Highway 56, Chauvin, Louisiana 70344, USA.

E-mail: hliu@lumcon.edu spp. and Synechococcus spp. and small eukaryotic algae. Together, they contribute substantially to both phytoplankton biomass and production in marine ecosystems. They are the dominant primary producers in oligotrophic warm waters, where they may account for up to $90 \%$ of the photosynthetic biomass and carbon production (e.g. Li et al. 1983, Campbell et al. 1994). Because their rapid growth rates are closely 
matched by mortality losses due to grazing by microzooplankton, they play an important role in nutrient regeneration and cycling in the ocean.

During the last decade, a large number of studies have been conducted on the geographical and vertical distributions, as well as diel, seasonal and inter-annual variations of Synechococcus spp. and Prochlorococcus spp. in the world oceans (see review by Partensky et al. 1999). In contrast, there are few studies on the dynamics of small eukaryotic algae. Several studies have found that small eukaryotic algae are very important in both biomass and carbon production in the world oceans. For example, Li (1995) found that, although Prochlorococcus spp. were the most abundant ultraphytoplankton $(<5 \mu \mathrm{m}$, sensu Murphy \& Haugen 1985), more than two-thirds of the ultraplankton biomass and productivity could be attributed to eukaryotic cells in the central North Atlantic. This is also true for most parts of the Arabian Sea (Campbell et al. 1998). However, few studies have been carried out in high-latitude regions such as the subartcic Pacific Ocean.

Heterotrophic bacterioplankton plays an important role in elemental cycling and trophic dynamics in the sea (Azam et al. 1983). Studies suggest that bacteria can consume about $50 \%$ of oceanic primary production daily (see review by Ducklow \& Carlson 1992). On the other hand, bacteria are consumed by heterotrophic flagellates and small ciliates (Fenchel 1984, Sherr \& Sherr 1987). Previous study revealed that bacterial biomass was about equal to phytoplankton biomass in the subarctic Pacific, but that bacteria consumed only 10 to $24 \%$ of primary production in the euphotic zone due to low bacterial growth rates (Kirchman et al. 1993).

The 2 gyre systems in the subarctic Pacific Ocean, the Alaskan Gyre (AG) in the east and the Western Gyre (WG) in the west, display distinctive differences in oceanographic and biogeochemical processes as well as microbial food-web dynamics. A comparative review of the factors controlling phytoplankton productivity in AG and WG has recently been conducted by Harrison et al. (1999). Despite the extensive studies on the community dynamics of picophytoplankton in the past few decades, their composition and distribution in the vast subarctic North Pacific, especially the WG, remain unstudied.

The AG is 1 of the 3 so-called high nutrient-low chlorophyll (HNLC) regions, where high levels of the major phytoplankton nutrients persist throughout the year but where substantial phytoplankton blooms are not observed (Miller et al. 1991). Chlorophyll a concentration in the euphotic zone is low $\left(\sim 0.4 \mathrm{mg} \mathrm{m}^{-3}\right)$ throughout the year (e.g. Wong et al. 1995), and phytoplankton biomass and primary production are dominated by pico- and nanophytoplankton (Booth 1988,
Booth et al. 1993, Welschmeyer et al. 1993, Boyd et al. $1995 a, b)$. There have been fewer studies of the WG. Phytoplankton blooms have been reported to occur in late spring and early summer, but mostly along the boundary of the gyre (e.g. Odate 1988-1989). During other periods, the WG has a higher chlorophyll a concentration but comparable primary production to the AG, indicating a lower chlorophyll-specific productivity (Shiomoto et al. 1998). Chlorophyll biomass in the WG is also dominated by small-sized cells (Odate 1996), although the composition of the picophytoplankton community has never been characterized. Here we report the first flow-cytometric study of picoplankton community structure in the subarctic North Pacific during a cross-basin investigation in summer 1999.

\section{MATERIALS AND METHODS}

Samples were collected at 15 stations in the subarctic North Pacific and Bering Sea during Cruise KH99-3 aboard the RV 'Hakuho Maru' in the early summer (June 25 to July 22) of 1999 (Fig. 1). The stations occupied during the cruise included the Japan JGOFS time-series station KNOT (Stn 1 in our study: $44^{\circ} \mathrm{N}$, $155^{\circ} \mathrm{E}$ ) and the Canadian ocean time-series station $\mathrm{P}$ (Stn 13 in our study: $50^{\circ} \mathrm{N}, 145^{\circ} \mathrm{W}$ ). Seawater was collected from 8 depths within the upper $100 \mathrm{~m}$ water column using Niskin bottles attached to a CTD rosette system. Sub-samples $(1 \mathrm{ml})$ were preserved with paraformaldehyde $(0.2 \%$ final concentration $)$, snapfrozen in liquid nitrogen, and stored at $-80^{\circ} \mathrm{C}$ until analysis (Vaulot et al. 1989).

A FACSCalibur flow cytometer equipped with a $15 \mathrm{~mW}$ laser exciting at $488 \mathrm{~nm}$ and the standard filter setup was used to enumerate the picoplankton. Samples were injected by an online infusion system with a controlled flow rate between 20 and $45 \mu \mathrm{min}^{-1}$ to keep the counting rate relatively constant. The analytical volume was determined by the rate and time of injection for each sample. At least 10000 events were counted for each sample. Forward and right angle light scatters (FSC and SSC) and green (515 to $545 \mathrm{~nm}$ ), orange (564 to $606 \mathrm{~nm}$ ) and red (>650 nm) fluorescence were collected, saved, and analyzed with CYTOWIN software (Vaulot 1989). All signals were normalized to that of $0.5 \mu \mathrm{m}$ Fluoresbrite YG beads (Polysciences) that were added to each sample. Two major groups of picophytoplankton, Synechococcus spp. and eukaryotic ultraplankton, were distinguished based on their autofluorescence properties (Fig. 2). Synechococcus spp. were distinguishable from the eukaryotic ultraplankton primarily by their strong orange fluorescence from phycoerythrin. In this paper, 


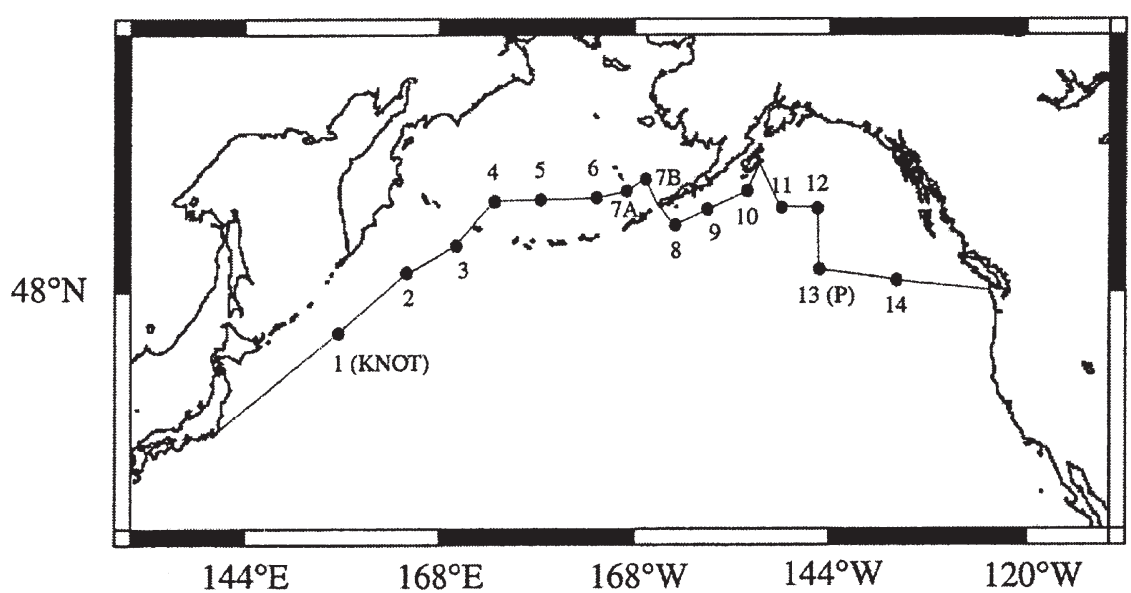

Fig. 1. Station locations on RV 'Hakuho Maru' Cruise KH99-3. KNOT: Japan JGOFS time-series station; P: Canadian Ocean time-series station

volume factor of $380 \mathrm{fgC}^{-3} \mathrm{~m}^{-3}$ (Lee \& Fuhrman 1987). This value is very close to the bacterial carbon content directly determined in various oceanic regions $\left(12.4 \pm 6.3 \mathrm{fgC} \mathrm{cell}^{-1}\right.$; mean $\left.\pm \mathrm{SD}\right)$ (Fukuda et al. 1998). Conversion factors for Synechococcus spp. in recent studies vary between $103 \mathrm{fgC} \mathrm{cell}^{-1}$ (Zubkov et al. 1998) and $400 \mathrm{fgC} \mathrm{Cell}^{-1}$ (Burkhill et al. 1993). Our conversion factor is consistent with those used in other recent JGOFS studies (i.e. Campbell et al. 1998, Brown et al. 1999). It is very difficult to obtain a conversion factor for eukaryotic ultraplankton without accurate measurements of cell size, since this plankton category is made up of many taxa and its composition varies spatially and

we use the term 'eukaryotic ultraplankton' for the population of small eukaryotes, which displays a highly variable size distribution, reflecting the taxonomic and morphological diversity of its component species. Most of these cells have equivalent spherical diameters around 1.2 and $2 \mu \mathrm{m}$ (Shalapyonok et al. 2001), but a small number of cells in the sizerange of nanoplankton was also included. Heterotrophic bacteria were enumerated in a separate subsample stained with the nucleic acid stain SYBR Green I (Marie et al. 1997). Working stocks of SYBR Green I $\left(10^{-3}\right.$ of the commercial solution) were freshly prepared on the day of analysis: $10 \%$ of the SYBR Green I working stock (vol:vol) was added to the samples, which were stored in the dark at room temperature for $30 \mathrm{~min}$ before analysis.

Hydrographic and nutrient data were obtained from the cruise report (Ocean Research Institute, University of Tokyo). Chlorophyll a concentrations were measured fluorometrically by filtering $200 \mathrm{ml}$ seawater onto $25 \mathrm{~mm}$ Whatman GF/F glass-fiber filters, extracting in $6 \mathrm{ml}$ of DMF for $24 \mathrm{~h}$ at $-20^{\circ} \mathrm{C}$, and then analyzing with a Turner Design fluorometer (Suzuki \& Ishimaru 1990).

In the literature, various carbon conversion factors have been derived by different approaches and employed for different geographic regions, but we found no reports of direct measurements of cell sizes and carbon content for picoplankton in the subarctic Pacific. We chose the factors 11, 175 and $1500 \mathrm{fgC}$ cell $^{-1}$ for heterotrophic bacteria (Garrison et al. 2000), Synechococcus spp. (Veldhuis et al. 1997) and eukaryotic ultraplankton (Zubkov et al. 1998), respectively. The bacterial carbon content of $11 \mathrm{fgC}^{\mathrm{Cell}^{-1}}$ we adopted is based on bacteria size measurements from the Arabian Sea (Ducklow et al. 2001) and a carbon per temporally. We based our value of $1500 \mathrm{fg} \mathrm{C} \mathrm{cell}^{-1}$ on cell size measurements of samples collected along a meridional transect in the Atlantic Ocean (Zubkov et

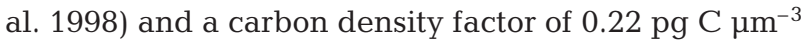
(Booth 1988). This latter value is intermediate among many others and is similar to recent estimates for the equatorial Pacific Ocean (Blanchot et al. 2001).

\section{RESULTS}

\section{Hydrographic data}

The sea surface temperature at Stn 1 was $6.8^{\circ} \mathrm{C}$, decreasing to around $6^{\circ} \mathrm{C}$ toward the Bering Sea; it then increased gradually to $10.5^{\circ} \mathrm{C}$ at the last station (Stn 14) (Table 1). The mixed-layer depth was shallow throughout the surveyed area, occurring at $20 \mathrm{~m}$ in the WG and increasing slightly to $30-40 \mathrm{~m}$ in the AG. Concentrations of macronutrients were high along the cruise track, with few exceptions (Table 1). Nitrate concentration was below the detection limit within the upper $20 \mathrm{~m}$ at $\mathrm{Stn} 7 \mathrm{~b}$, the only shallow water station on the continental shelf of Alaska, where silicate concentration was also low $(1.5 \mu \mathrm{M})$. Lower nitrate concentrations $(<0.5 \mu \mathrm{M})$ also occurred at Stns 8 and 10 along the Aleutian Trench. A near-zero $(0.02 \mu \mathrm{M})$ silicate concentration was found at Stn 5 in the Bering Sea, indicating that a diatom bloom could have occurred earlier in this region.

Chlorophyll a concentrations were generally below $1 \mathrm{mg} \mathrm{m}^{-3}$ in both the WG and the AG, but generally higher than $1 \mathrm{mg} \mathrm{m}^{-3}$ in the Bering Sea (Table 1). A very high chlorophyll a concentration $\left(3.75 \mathrm{mg} \mathrm{m}^{-3}\right.$ ) was measured in the surface water at Stn 10, where both nitrate and silicate concentrations were low $(0.5$ 

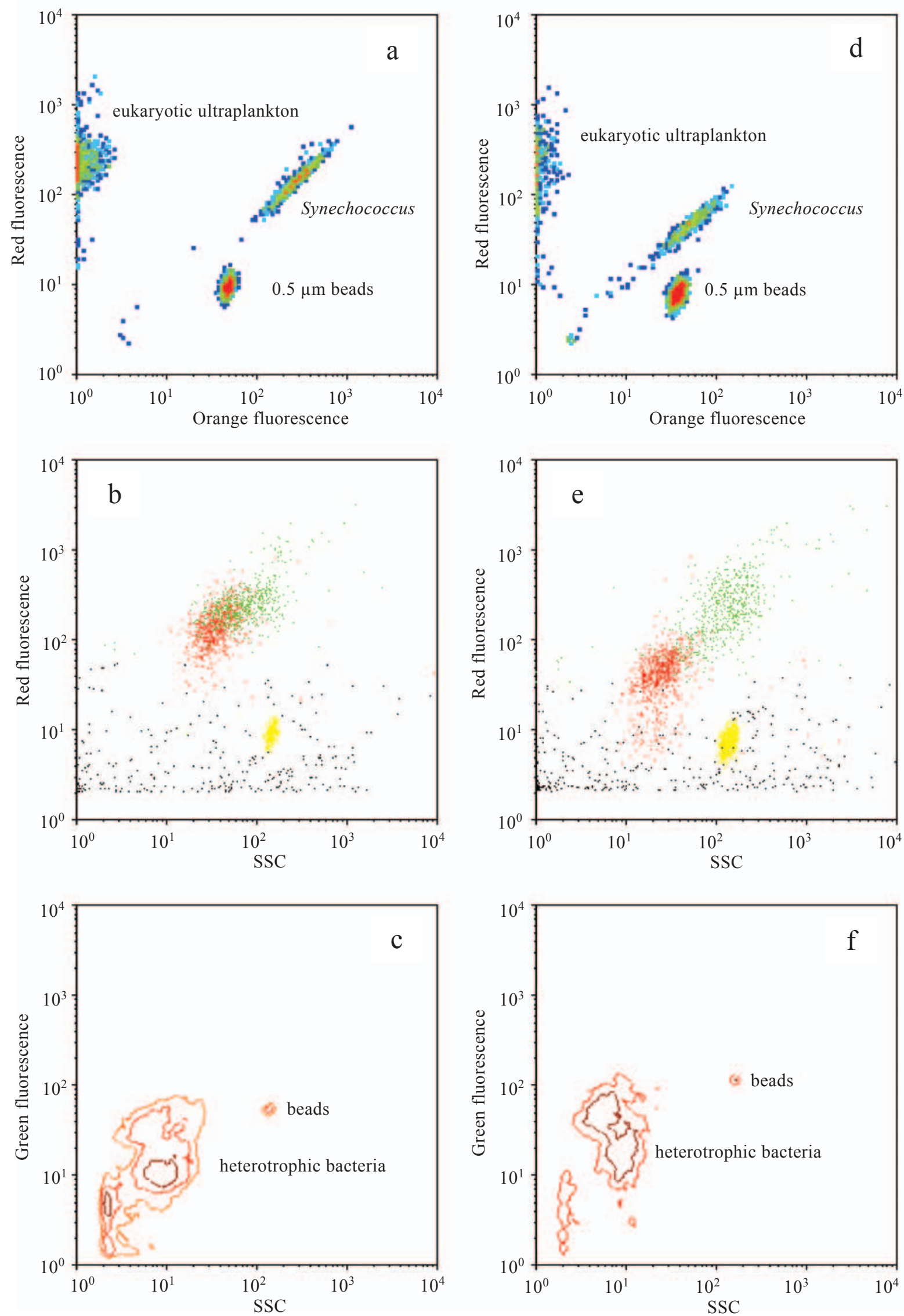
Fig. 2. Examples of flow cytometry cytograms. Data of samples taken from $20 \mathrm{~m}$ at Stn KNOT $(\mathrm{a}, \mathrm{b}, \mathrm{c})$ on June 28 and Stn $\mathrm{P}(\mathrm{d}, \mathrm{e}, \mathrm{f})$ on July 17, 1999. (a,d) Red (chlorophyll-derived) fluorescence vs orange (phycobiliprotein-derived) fluorescence of unstained samples; Synechococcus spp. are easily distinguishable from eukaryotic ultraplankton by their strong orange fluorescence. $(\mathrm{b}, \mathrm{e})$ Red fluorescence vs side scatter (SSC) of unstained samples; Synechococcus spp. (red dots) and eukaryotic ultraplankton (green dots) populations are mainly overlapping in the Stn KNOT sample. (c,f) Green fluorescence vs SSC signals for a SYBR Green I-stained sample. Autotrophic picoplankton cells are not shown because or their much lower abundances

and $1.35 \mu \mathrm{M}$, respectively), suggesting that the high chlorophyll a concentration resulted from a diatom bloom. A study of the chemotaxonomic pigments showed that diatoms accounted for more than $50 \%$ of the total chlorophyll a concentration at Stn 10 (Suzuki et al. 2002).

\section{Picoplankton distribution}

Flow-cytometry analysis revealed that the picoplankton community in the studied area was comprised of Synechococcus spp., eukaryotic ultraplankton and heterotrophic bacteria. Prochlorococcus spp. were not detected at any station. At Stn KNOT, abundances of Synechococcus spp. were about $10^{4}$ cells $\mathrm{ml}^{-1}$ in the upper $40 \mathrm{~m}$ of the water column, decreasing to less than $10^{3}$ cells ml ${ }^{-1}$ below $60 \mathrm{~m}$ (Stn 1 in Fig. 3). Eukaryotic ultraplankton abundances were approximately twice that of Synechococcus spp., with a similar depthwise distribution. This trend was also observed at Stn 2. Further north (Stn 3), the abundance of eukaryotic ultraplankton remained high whereas that of Synechococcus spp. decreased. Abundances of Synechococcus spp. and eukaryotic ultraplankton were low in the southern Bering Sea (Stns 4 to 6). We observed the highest eukaryotic ultraplankton density $\left(4 \times 10^{4}\right.$ cells ml $\mathrm{m}^{-1}$ at $\left.20 \mathrm{~m}\right)$ at Stn 7 a on the continental slope of the SE Bering Sea. A subsurface maximum of Synechococcus spp. with abundances attaining 6 to $8 \times 10^{4}$ cells $\mathrm{ml}^{-1}$ was observed in the northern AG (Stns 9, 11 and 12). Stn $P$ was characterized by low abundances $\left(<10^{3}\right.$ cells $\left.\mathrm{ml}^{-1}\right)$ and deeper distributions of both populations.

Counts of heterotrophic bacteria were about 2 orders of magnitude higher than those of Synechococcus spp. and eukaryotic ultraplankton, with higher abundance generally occurring in the area of high autotrophic biomass (Fig. 4). Maximum bacterial abundance usually occurred either at the surface or between 20 and $50 \mathrm{~m}$ depths. Bacterial abundance at $100 \mathrm{~m}$ depth remained high at 4 to $5 \times 10^{4}$ cells $\mathrm{ml}^{-1}$ throughout the cruise.

Although some of the stations were not located in either gyre system, we nevertheless divided all stations into 3 geographic groups, i.e. the WG (Stns 1 to 3), Bering Sea (Stns 4 to $7 \mathrm{~b}$ ) and AG (Stns 8 to 14), for comparison. The average depth-integrated abundance of Synechococcus spp. was highest in the AG and lowest in the southern Bering Sea (Table 2). Abundances of eukaryotic ultraplankton and heterotrophic bacteria were less variable among the 3 regions, with higher abundances in the WG.

\section{Biomass estimates}

Although Synechococcus spp. and eukaryotic ultraplankton displayed comparable abundances, the latter contributed significantly more to photosynthetic carbon biomass, except at Stns 11 and 12 in the northern Gulf of Alaska, where the biomass of Synechococcus spp. and of eukaryotic ultraplankton were approximately equal (Fig. 4b). Synechococcus spp. biomass was especially low in the Bering Sea. The ratios of Synechococcus spp. to eukaryotic ultraplankton in terms of carbon biomass were $1: 13$ for the WG, 1:21 for the southern Bering Sea, and 1:2.8 for the AG (Table 2).

Bacterial biomass was less variable than that of Synechococcus spp. or eukaryotic ultraplankton throughout the surveyed area and was comparable to the biomass of autotrophic picoplankton, except in the

Table 1. Hydrographic data, nutrient and chlorophyll a concentrations of the surface water at each station during the survey

\begin{tabular}{|lccccc|}
\hline Stn & $\begin{array}{c}\text { Temperature } \\
\left({ }^{\circ} \mathrm{C}\right)\end{array}$ & $\begin{array}{c}\text { Salinity } \\
(\%)\end{array}$ & $\begin{array}{c}\mathrm{NO}_{3} \\
(\mu \mathrm{M})\end{array}$ & $\begin{array}{c}\mathrm{SiO}_{2} \\
(\mu \mathrm{M})\end{array}$ & $\begin{array}{c}\mathrm{Chl} \mathrm{a} \\
\left(\mathrm{mg} \mathrm{m}^{-3}\right)\end{array}$ \\
\hline 1 & 6.8 & 32.84 & 9.8 & 1.7 & 0.38 \\
2 & 5.8 & 32.89 & 21.6 & 40.1 & 0.55 \\
3 & 6.1 & 32.71 & 12.9 & 18.5 & 0.43 \\
4 & 6.3 & 33.12 & 19.1 & 26.9 & 1.86 \\
5 & 6.4 & 33.04 & 11.2 & 0.02 & 1.40 \\
6 & 7.0 & 32.04 & 14.7 & 21.7 & 0.52 \\
$7 \mathrm{a}$ & 7.9 & 32.88 & 3.0 & 13.9 & 1.02 \\
$7 \mathrm{~b}$ & 8.0 & 32.04 & 0.0 & 1.5 & 0.30 \\
8 & 9.1 & 32.63 & 0.4 & 19.8 & 0.56 \\
9 & 9.5 & 32.75 & 8.0 & 6.6 & 0.47 \\
10 & 9.9 & 32.38 & 0.5 & 1.4 & 3.75 \\
11 & 9.5 & 32.90 & 15.3 & 19.6 & 0.45 \\
12 & 10.1 & 32.77 & 10.7 & 16.3 & 0.37 \\
13 & 10.1 & 32.74 & 11.1 & 17.8 & 0.28 \\
14 & 10.5 & 32.69 & 7.2 & 9.7 & 0.40 \\
\hline
\end{tabular}



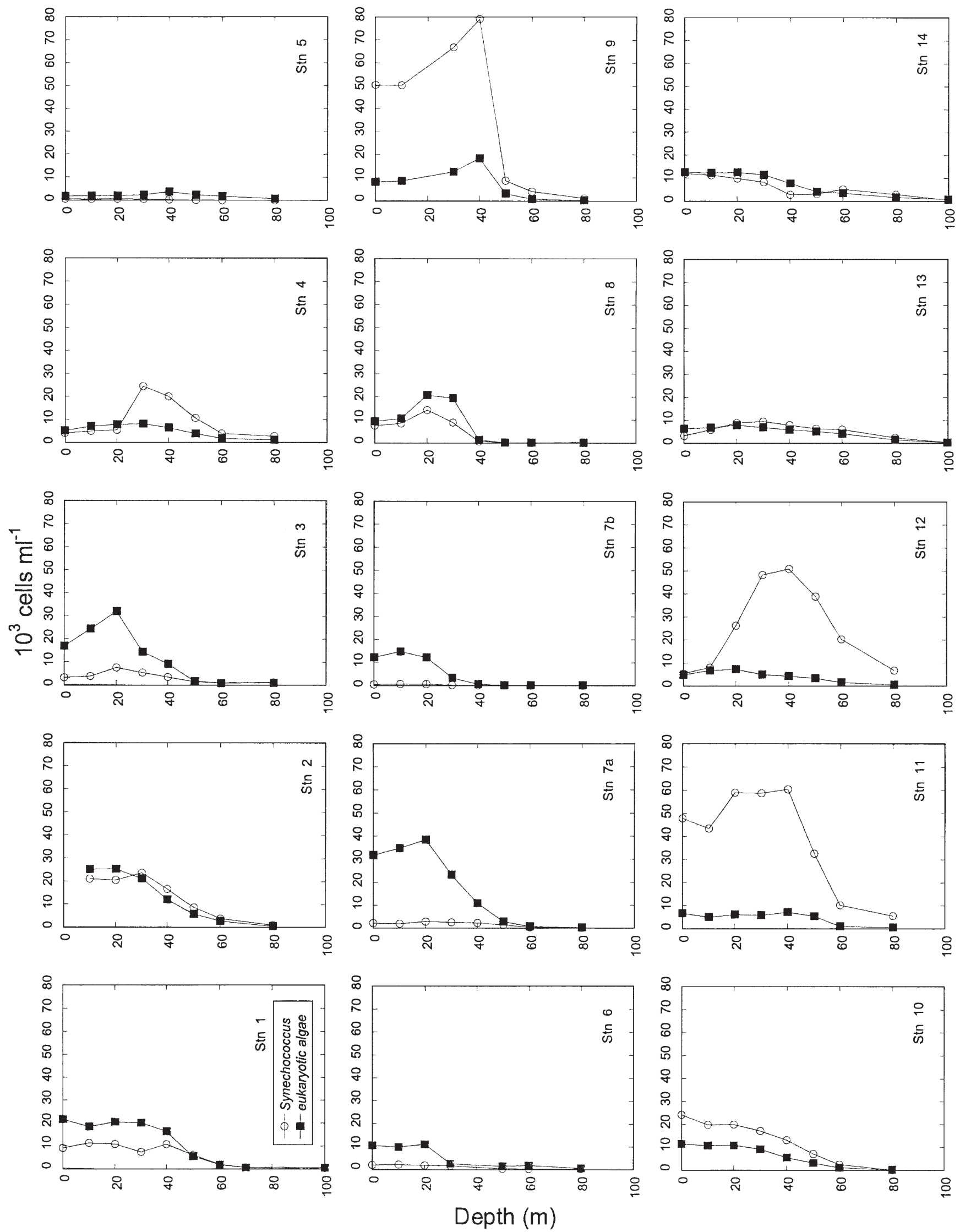
Fig. 3. Vertical profiles of Synechococcus and eukaryotic ultraplankton abundances at each station in the subarctic Pacific during summer 1999

WG, where the biomass of heterotrophic bacteria was lower than that of picophytoplankton (Fig. 4b). Depthintegrated (0 to $100 \mathrm{~m}$ ) total picoplankton biomass was estimated at $2533 \mathrm{mg} \mathrm{C} \mathrm{m}^{-2}$ (62.5\% autotrophic) for the WG, $1575 \mathrm{mg} \mathrm{C} \mathrm{m}^{-2}$ (51.4\% autotrophic) for the southern Bering Sea, and $1899 \mathrm{mgC} \mathrm{m}^{-2} \quad(52.1 \%$ autotrophic) for the AG.

\section{Cellular characteristics of Synechococcus spp. and eukaryotic ultraplankton}

Cellular red fluorescence and FSC per cell increased with increasing depth for Synechococcus spp. and eukaryotic ultraplankton (Fig. 5). The average cellular red fluorescence increased by a factor of 4 and 2 for
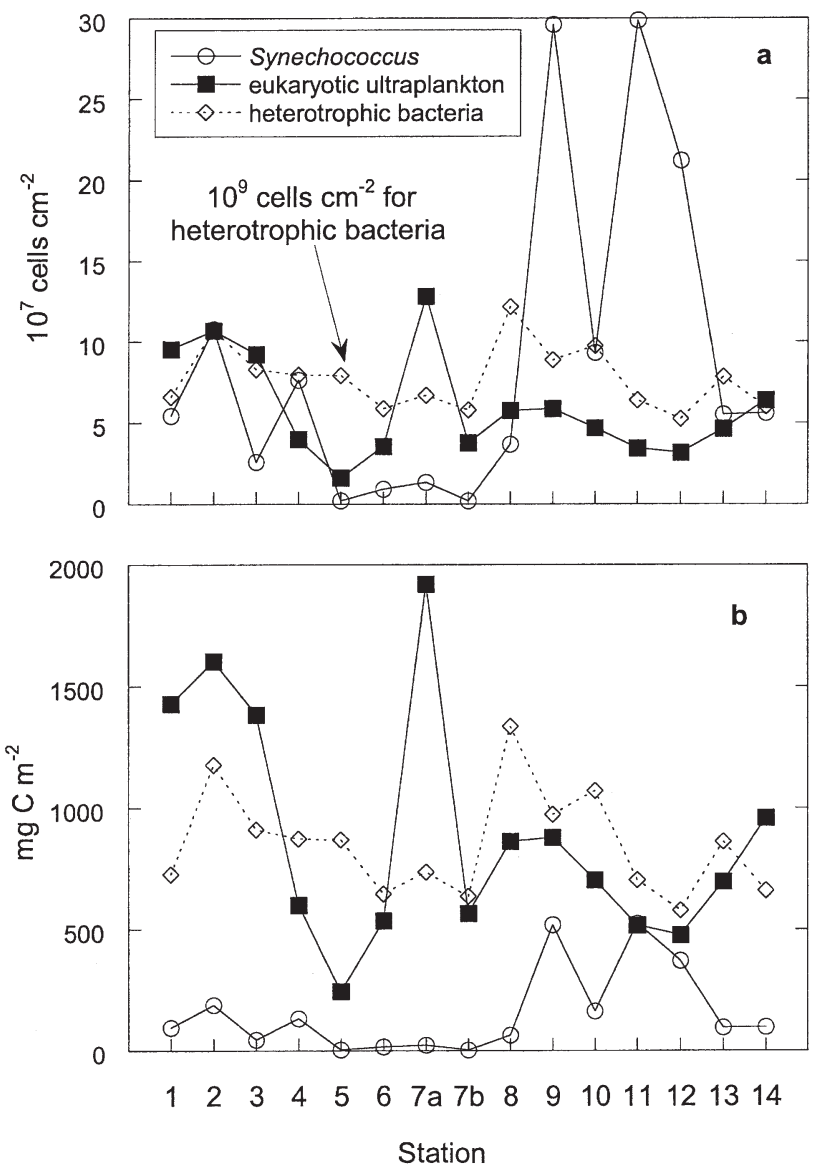

Fig. 4. Depth-integrated (0 to $100 \mathrm{~m}$ ) abundances (a) and carbon biomass (b) of Synechococcus spp., eukaryotic ultraplankton and heterotrophic bacteria along a transect from western to eastern subarctic Pacific during summer 1999
Synechococcus spp. and eukaryotic ultraplankton, respectively, from the surface to the bottom of the euphotic layer. At the same time, the FSC per cell increased only slightly for Synechococcus spp. and nearly doubled for eukaryotic ultraplankton (Fig. 5). The standard deviations for both parameters increased with increasing depth, suggesting higher variability in the deeper euphotic layer.

Geographically, both parameters fluctuated 2- to 3fold along the transect (Fig. 6). The highest red fluorescence and FSC per cell for Synechococcus spp. and eukaryotic ultraplankton occurred in the Bering Sea. The 2 parameters co-varied over most of the surveyed area, with a few exceptions; e.g. while the FSC remained high, the red fluorescence of Synechococcus spp. was very low at Stn $7 b$, where nitrate concentration was undetectable. At the same station, the red fluorescence and FSC of eukaryotic ultraplankton were also the lowest among all stations.

\section{DISCUSSION}

\section{Importance of picoplankton in nutrient-rich cold waters}

Our results demonstrate that small eukaryotes are the dominant contributor to pico-autotrophic biomass in the subarctic North Pacific and the southern Bering Sea. Prochlorococcus spp. were not detected at any station. Although it has been reported to occur as far north as $60^{\circ} \mathrm{N}$ in the North Atlantic (Buck et al. 1996), its distribution in the North Pacific appears to be limited to the south of $45^{\circ} \mathrm{N}$. We believe that the

Table 2. Picoplankton abundance $\left(10^{7}\right.$ cells $\left.\mathrm{cm}^{-2}\right)$ and biomass $\left(\mathrm{mg} \mathrm{C} \mathrm{m}^{-2}\right)$ for 3 geographic regions. WG: western gyre; SBS: southern Bering Sea; AG: Alaskan gyre

\begin{tabular}{|lccc|}
\hline Species & WG & SBS & AG \\
\hline Abundance & & & \\
Synechococcus spp. (Syn) & 6.28 & 2.06 & 14.98 \\
Eukaryotic ultraplankton (Euk) & 9.81 & 5.15 & 4.85 \\
Heterotrophic bacteria & 865 & 696 & 827 \\
Syn:Euk & $1: 1.6$ & $1: 2.5$ & $1: 0.3$ \\
Carbon biomass & & & \\
Synechococcus spp. (Syn) & 109.9 & 36.2 & 262.1 \\
Eukaryotic ultraplankton (Euk) & 1472.1 & 773.1 & 727.5 \\
Heterotrophic bacteria & 951.2 & 765.1 & 710.0 \\
Syn:Euk & $1: 13.4$ & $1: 21.4$ & $1: 2.8$ \\
\hline
\end{tabular}



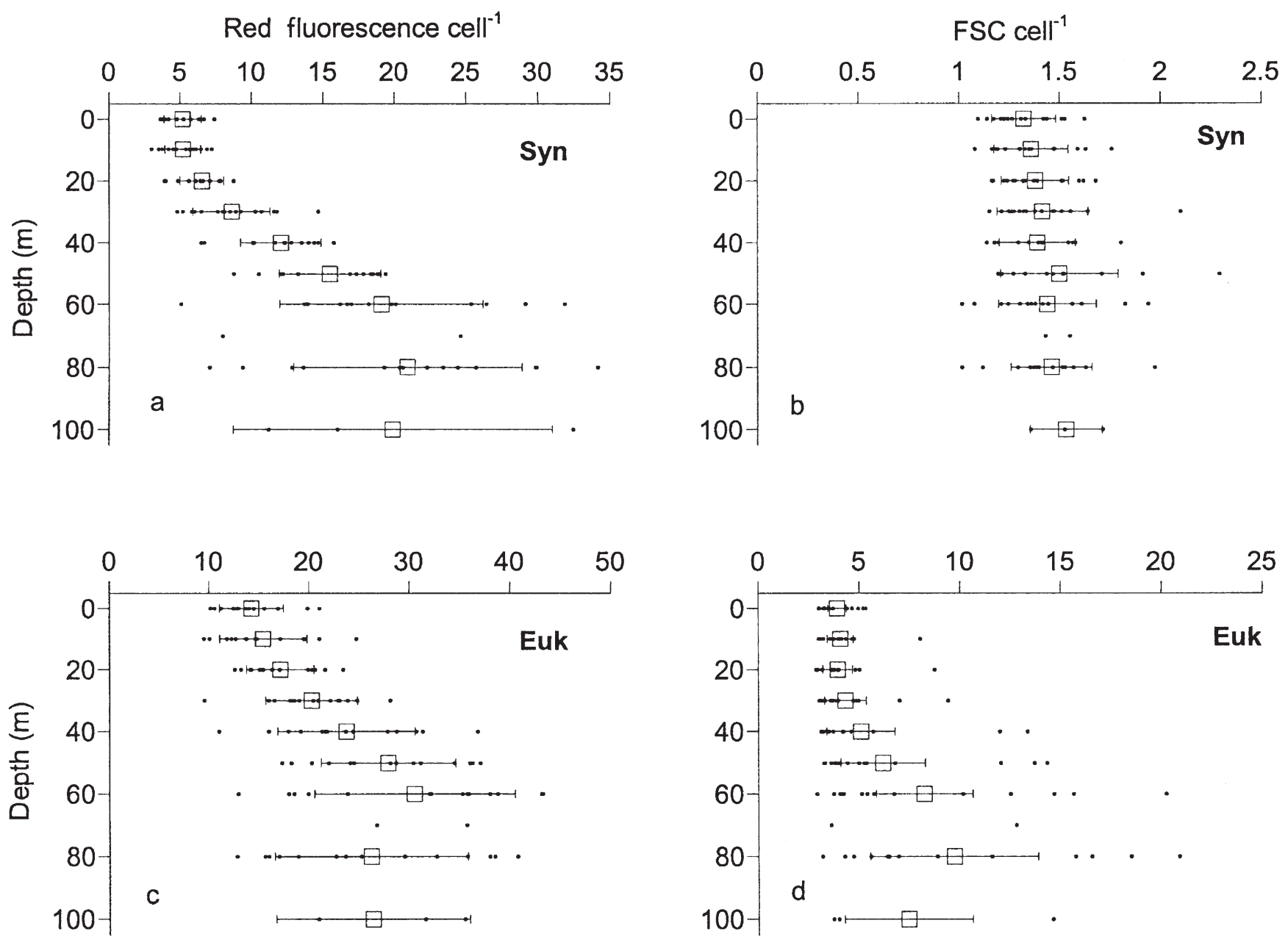

Fig. 5. Depth profiles of red fluorescence and forward light scatter (FSC) per cell for Synechococcus spp. (a,b) and eukaryotic ultraplankton (c,d) in the subarctic Pacific during summer 1999. Open squares show the mean of all profiles and error bars the standard deviations

absence of Prochlorococcus spp. in the subarctic North Pacific water north of $45^{\circ} \mathrm{N}$ is related to the lower sea surface temperature and salinity in the North Pacific than in the North Atlantic (see also Partensky et al. 1999). In contrast to Prochlorococcus, Synechococcus spp. occurred at all stations and bloomed in the northern Gulf of Alaska. However, its contribution to photosynthetic biomass remained small compared to that of the eukaryotic ultraplankton. This observation is in agreement with previous studies (i.e. Boyd \& Harrison 1999, Obayashi et al. 2001).

The fact that eukaryotic ultraplankton were more important than Synechococcus spp. in terms of carbon biomass is explained by the higher carbon per cell value of eukaryotic ultraplankton compared to Synechococcus. As pointed out earlier ('Materials and methods'), the carbon per cell value of $175 \mathrm{fgC} \mathrm{cell}^{-1}$ for Synechococcus spp. is roughly intermediate among numerous estimates in the literature, and is supported by recent studies (see also Liu et al. 1999). Estimating carbon biomass for eukaryotic ultraplankton from a single conversion factor is more arbitrary due to the heterogeneousness of this group. Nevertheless, data from different oceanic regions have all revealed a larger cell size and carbon content of eukaryotic ultraplankton than of Synechococcus. The carbon content of broadly defined picoeukaryotes (i.e. including cells $>2 \mu \mathrm{m}$ ) based on direct cell-size measurements ranges from 975 to $2500 \mathrm{fgC}$ cell $^{-1}$ (Campbell et al. 1994, Reckermann \& Veldhuis 1997, Zubkov et al. 1998, Blanchot et al. 2001). Our conclusions regarding the relative contributions of Synechococcus spp. and eukaryotic ultraplankton to total autotrophic picoplanktonic biomass remain unaffected even when the lowest reported carbon per cell value for eukaryotic ultraplankton is applied. 

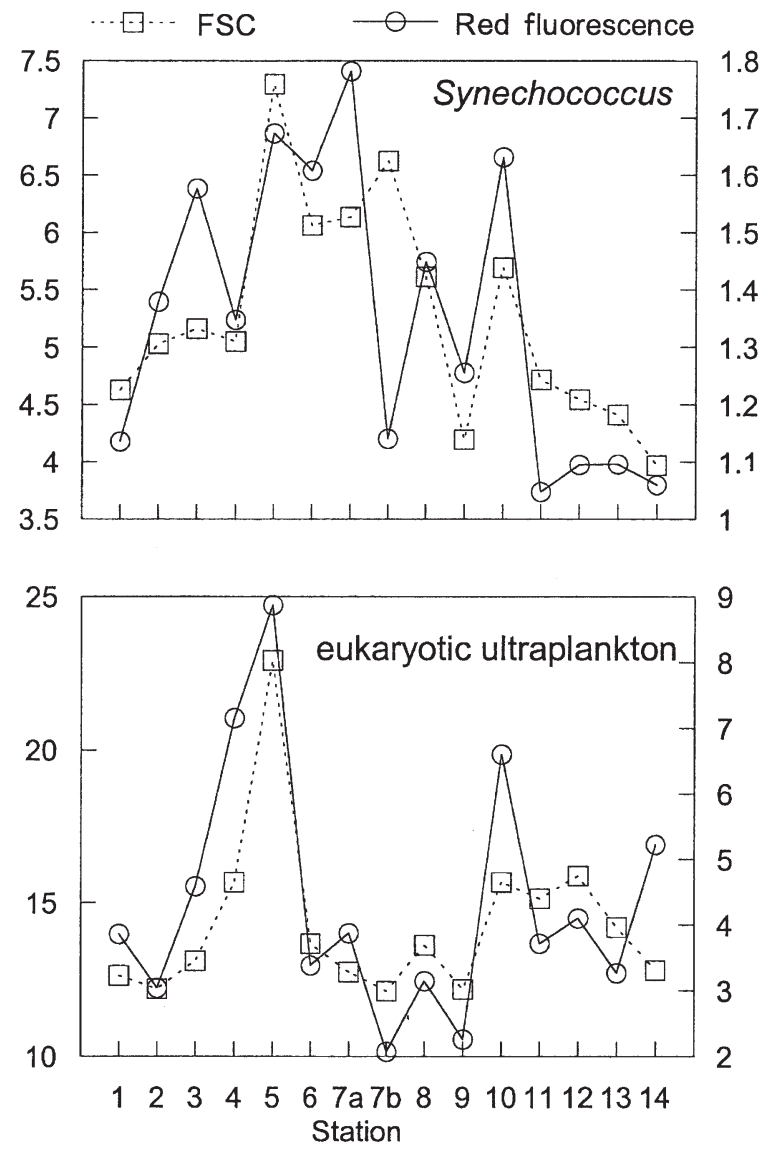

Fig. 6. Cellular red fluorescence and FSC in surface populations of (a) Synechococcus and (b) eukaryotic ultraplankton along a transect from the western to the eastern subarctic Pacific during summer 1999
With no direct measurement of the carbon content of large algae available, we used an approximate C:chlorophyll a (C:chl) ratio of 50 (mean calculated from the SUbarctic Pacific Ecosystem Research [SUPER] data base; see also Booth et al. 1993, Boyd \& Harrison 1999) to calculate the total phytoplankton carbon biomass from chlorophyll a. We realize the limitations of this approach, since field measurements and modelling studies have indicated large temporal and spatial variations in the C:chl ratio (e.g. Booth et al. 1993, Buck et al. 1996, Taylor et al. 1997). Nevertheless, the relative contribution of picophytoplankton to total autotrophic biomass estimated by this approach was in agreement with other independent estimates such as the size-fractionated chlorophyll measurements (I. Kudo pers. comm.) and chemotaxonomic composition revealed by HPLC pigment analysis (Suzuki et al. 2002). For example, on the same cruise, sizefractionated chlorophyll a measurements revealed that 72,30 and $35 \%$ of the chlorophyll $a$ at $5 \mathrm{~m}$ at Stns 1, 5 and 13 was from the $<2 \mu \mathrm{m}$ fraction. For these stations, our results indicate that picophytoplankton accounted for 71,8 and $45 \%$ of the total photosynthetic biomass, respectively. The lower picophytoplankton biomass estimated from the flow cytometry data for Stn 5 may indicate that the carbon per cell value used in our study is too small for the populations in the Bering Sea. The average size of the eukaryotic ultraplankton at Stn 5 was about twice as large as those at Stns 1 and 13 (see following discussion and Table 3).

Based on the above estimates, we conclude that picophytoplankton was an important contributor to

Table 3. Vertical variations in cellular red (chlorophyll) fluorescence and forward light scatter (FSC) for Synechococcus and eukaryotic ultraplankton at 3 stations representing the western gyre (Stn 1), the southern Bering Sea (Stn 5) and the Alaskan gyre (Stn 13). All signals were normalized to $0.5 \mu \mathrm{m}$ beads (see 'Materials and methods'). The depths for the 'deep' population were the depths where maximal cellular red fluorescence was observed, except for eukaryotic ultraplankton at Stn 5, for which the depth of maximal FSC was chosen because the cellular red fluorescence decreased with increasing depth. Cell volumes were calculated from FSC using the empirical formula of Binder et al. (1996)

\begin{tabular}{|c|c|c|c|c|c|c|}
\hline \multirow{2}{*}{ Depth } & \multicolumn{3}{|c|}{ Synechococcus } & \multicolumn{3}{|c|}{ Eukaryotic ultraplankton } \\
\hline & Stn 1 & Stn 5 & Stn 13 & Stn 1 & Stn 5 & Stn 13 \\
\hline \multicolumn{7}{|l|}{ Red fluorescence } \\
\hline Surface & 4.79 & 6.87 & 3.98 & 13.98 & 24.72 & 12.72 \\
\hline Deep $^{a}$ & 25.35 & 17.83 & 32.44 & 35.72 & 19.91 & 31.57 \\
\hline Deep:surface & 6.05 & 2.60 & 8.15 & 2.56 & 0.81 & 2.48 \\
\hline \multicolumn{7}{|l|}{ FSC } \\
\hline Surface & 1.23 & 1.76 & 1.18 & 3.23 & 8.03 & 3.96 \\
\hline Deep $^{a}$ & 1.56 & 2.29 & 1.36 & 3.61 & 20.23 & 3.74 \\
\hline Deep:surface & 1.28 & 1.30 & 1.15 & 1.12 & 2.52 & 0.94 \\
\hline \multicolumn{7}{|c|}{ Change in cell volume } \\
\hline Deep:surface & 1.15 & 1.16 & 1.08 & 1.06 & 1.67 & 0.97 \\
\hline \multicolumn{7}{|c|}{ Change in C:chl ratio } \\
\hline Deep:surface & 5.26 & 2.24 & 7.55 & 2.40 & 0.48 & 2.56 \\
\hline
\end{tabular}



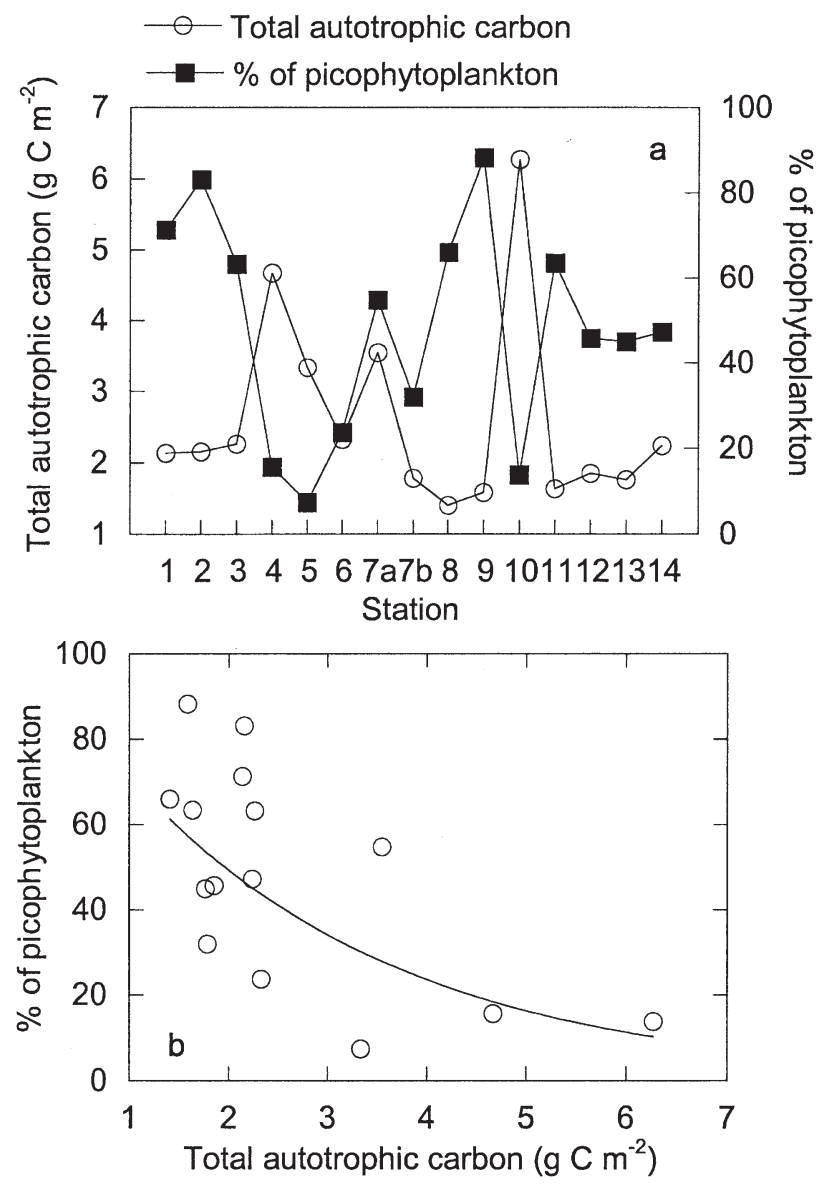

Fig. 7. (a) Total phytoplankton carbon biomass and percentage contribution by picophytoplankton at each station along a transect from the western to the eastern subarctic Pacific during summer 1999; (b) plot of picophytoplankton contributions against total autotrophic biomass, line is exponential curve $(\mathrm{r}=0.65)$

photosynthetic biomass in both gyres of the subarctic North Pacific Ocean, accounting for about $50 \%$ or more of the total phytoplankton carbon (Fig. 7). There was one exception at Stn 10, where very high chlorophyll a (up to $4 \mathrm{mg} \mathrm{m}^{-3}$ ) resulted from a diatom bloom (Suzuki et al. 2002), thereby lowering the contribution of picophytoplankton to the total photosynthetic carbon. This diatom bloom probably resulted from a greater supply of iron arising from the proximity of this station to land. The iron concentration in the surface water of this station was rather high $(0.92 \mathrm{nM}$; data courtesy of Dr. H. Obata).

In general, the Bering Sea had a higher phytoplankton standing stock and a lower picophytoplankton stock during early summer. HPLC pigment analysis revealed that diatoms accounted for more than half of the total chlorophyll $a$ in the Bering Sea during our study (Suzuki et al. 2002). The proportion of picoplank- ton contribution was inversely weakly correlated to total phytoplankton biomass (Fig. 7b). This is in agreement with the general pattern observed by Agawin et al. (2000), who compiled 38 published reports from different oceanic and coastal waters. Among these reports, however, only 1 study, in the subarctic North Pacific and Bering Sea (Shiomoto et al. 1997), measured size-fractionated chlorophyll a concentration and primary productivity.

\section{Phytoplanktonic and bacterial biomass}

The bacterial abundances measured in the present study $\left(0.6\right.$ to $1.5 \times 10^{6}$ cells $\mathrm{ml}^{-1}$ in the surface waters) were higher than those in the subtropical North Pacific ( 0.25 to $0.55 \times 10^{6}$ cells ml $^{-1}$; Campbell et al. 1994$)$, but within the range observed in the Atlantic Ocean between 50 and $61^{\circ} \mathrm{N}$ during summer (Buck et al. 1996). Our bacterial abundance data are reasonably comparable to counts derived from epifluorescence microscopy using the procedure of Porter \& Feig (1980). Integrated bacterial abundance in the upper $100 \mathrm{~m}$ water column at Stns 1, 5 and 13 was $6.48,8.51$ and $8.71 \times 10^{9}$ cells cm $\mathrm{cm}^{-2}$ using flow-cytometry analysis, and $5.39,6.42$ and $9.30 \times 10^{9}$ cells $\mathrm{cm}^{-2}$ using epifluorescence microscopy counting (data courtesy of N. Yamada and E. Tanoue), respectively.

Bacterial biomass was lower than phytoplankton biomass in the subarctic North Pacific and the Bering Sea in our study. The average bacterial biomass was $27 \%$ (range 15 to $49 \%$ ) of the sum of bacterial and phytoplankton biomass integrated through $100 \mathrm{~m}$. Some previous studies have reported significantly higher bacterial biomass than phytoplankton biomass in the open ocean (e.g. Fuhrman et al. 1989, Cho \& Azam 1990). However, in these previous studies, bacterial biomass may have been overestimated by epifluorescence microscopy cell counts, particularly for the oligotrophic open ocean, where photosynthetic Prochlorococcus spp. comprise a considerable percentage of the total bacteria, from which they cannot be separated by epifluorescence microscopy (Campbell et al. 1994). It should be noted that we applied a smaller conversion factor to convert bacterial cell abundance to carbon biomass in this study. Bacterial biomass during the period of our study would be almost equal to phytoplankton biomass were we to use the same conversion factor (20 $\mathrm{fg} \mathrm{C} \mathrm{cell}^{-1}$; Lee \& Fuhrman 1987) as that used by Kirchman et al. (1993), who reported bacterial biomass to be roughly equal to phytoplankton biomass.

Furthermore, flow cytometry counting of picophytoplankton and bacterial abundance below $100 \mathrm{~m}$ at 2 stations (Stns 1 and 13) revealed that bacterial abundance between 100 and $200 \mathrm{~m}$ averaged $30 \%$ of that in 
the upper $100 \mathrm{~m}$ water column. In contrast, there were virtually no phytoplankton cells below $100 \mathrm{~m}$. Therefore, bacterial biomass surpassed phytoplankton biomass in the upper $200 \mathrm{~m}$ water column in the AG and southern Bering Sea, but was slightly less than the phytoplankton biomass in the WG during our study. The high bacterial biomass but low bacterial production in the subarctic North Pacific has been attributed to a low bacteria growth rate that is probably due to low temperature and low DOM concentration (Kirchman et al. 1993).

\section{Physiological variability or picoplankton diversity?}

The FSC signal of a particle is a function of its size and, to a lesser extent, of its refractive index and shape (Ackelson \& Spinrad 1988). We used the approach described in Binder et al. (1996) to calculate the cell volume from FSC signals based on the relationship $\mathrm{FSC} \propto(\text { cell volume })^{\beta}$, where $\beta$ is a constant specific for the cell type in question (Morel 1991). We used a $\beta$ value of 1.80 determined empirically for Synechococcus spp. by DuRand (1995) for both Synechococcus spp. and eukaryotic ultraplankton. Extension of this value to eukaryotic ultraplankton is validated by the similar $\beta$ value calculated for Prochlorococcus, Synechococcus spp. and eukaryotic ultraplankton in the equatorial Pacific (Binder et al. 1996, Blanchot et al. 1997, 2001). Nevertheless, we shall only discuss the relative change of these parameters instead of their absolute values, because the estimated cell size for both Synechococcus spp. and eukaryotic ultraplankton in this study is significantly smaller than that estimated by Blanchot et al. (2001) for living cells in the equatorial Pacific. The unreasonably small cell size is almost certainly a result of cell shrinkage caused by sample preservation and storage.

One of the reasons for the increased variability in cellular red fluorescence and FSC in the deeper layers (Fig. 5) was the apparent existence of several vertical variation patterns of these parameters. While in most cases both parameters increased with depth, 1 or both remained relatively unchanged or even decreased with depth at some locations. Using Stns 1, 5 and 13 to represent the 3 sub-regions of our study, the WG, Bering Sea and AG, some differences in cellular properties and variation patterns among different regions are apparent. Table 3 shows that both Synechococcus spp. and eukaryotic ultraplankton cells in the Bering Sea have a much higher red fluorescence and FSC, and hence are larger and contain more chlorophyll $a_{\text {, }}$ than cells in the subarctic North Pacific gyres. Changes in cellular red fluorescence and FSC in Prochlorococcus spp. have been interpreted as reflecting shifts among different strains as well as physiological shifts within a given species (Campbell \& Vaulot 1993, Moore et al. 1995). Liu et al. (1999) reported that red fluorescence and FSC in a given Synechococcus spp. strain changed dramatically under different nutrient conditions and growth rates. It is likely that there were different species of Synechococcus spp. and eukaryotic ultraplankton living in different regions of the study area. This is particularly true for eukaryotic ultraplankton because they are composed of many taxonomic groups of small eukaryotic algae.

The red fluorescence per cell increased in general with increasing depth as expected, reflecting the increase in cellular chlorophyll a content at low light intensities. However, the cellular red fluorescence of eukaryotic ultraplankton at Stn 5 in the Bering Sea actually decreased with depth (Table 3 ). This, together with the large increase in FSC per cell, clearly indicates a shift from small but high chlorophyll-containing species at the surface to large but less chlorophyllcontaining cells, perhaps some types of mixotroph, in the deep euphotic layer. Assuming that red fluorescence is proportional to chlorophyll a content and carbon content is proportional to cell volume, the C:chlorophyll ratio for Synechococcus spp. changed 2to 8-fold between the surface and the bottom of the euphotic layer. The C:chlorophyll ratio of eukaryotic ultraplankton increased more than 2 -fold at 2 stations in the subarctic gyres, but decreased by about $50 \%$ at Stn 5 in the Bering Sea from the surface to the deep euphotic layer (Table 3). It should be pointed out that comparison of red fluorescence and FSC per cell between different taxonomic groups has to be made with some caution (Sosik et al. 1989, Morel 1991).

The vertical variability in chlorophyll fluorescence for Synechococcus spp. and eukaryotic ultraplankton observed in the subarctic North Pacific and the Bering Sea was very small compared to that observed in tropical and subtropical waters. For instance, Campbell \& Vaulot (1993) reported a 25- to 40-fold change in chlorophyll fluorescence for Synechococcus spp. and an up to 7 -fold increase for eukaryotic ultraplankton from the surface to below the deep chlorophyll maximum layer in the oligotrophic subtropical North Pacific Gyre. The very low chlorophyll fluorescence from the surface populations in oligotrophic warm waters probably results from extremely low nutrient concentrations, high water temperature and high surface irradiance. Smaller cells have greater potential for photodamage from both photosynthetically active radiation and UV-B because of their smaller package effect (Raven 1998). We observed higher vertical variation in cellular chlorophyll fluorescence in the subarctic North Pacific than in the Bering Sea. Whether this difference is due to differences in temperature and radiation, or is 
a result of differences in cell size or species composition, requires further study.

\section{Comparison between the WG and AG}

The eastern part of the subarctic North Pacific, the $\mathrm{AG}$, is a high nutrient-low chlorophyll (HNLC) region where high concentrations of essential nutrients, $\mathrm{NO}_{3}$, $\mathrm{PO}_{4}$, and $\mathrm{SiO}_{2}$, persist year-round. The lack of phytoplankton blooms in the HNLC regions has been attributed to limitation through iron deficiency (Martin \& Fitzwater 1988) and microzooplankton grazing (Miller et al. 1991). Fe limitation favors the growth of small cells, thus allowing increased grazing by microzooplankton. Grazing efficiently recycles nitrogen as $\mathrm{NH}_{4}{ }^{+}$, which strongly inhibits the uptake of $\mathrm{NO}_{3}{ }^{-}$ (Varela \& Harrison 1999), leaving the system persistently rich in major nutrients (Miller et al. 1991).

There is a general perception that a phytoplankton spring bloom occurs in the WG, but most previous reported blooms were in the boundary area either in the front between the Oyashio and Kuroshio extensions (Parsons \& Anderson 1970, Odate \& Maita 1988-1989), or along the Kurile Islands (Taguchi et al. 1992). Chlorophyll a concentration and primary production in most parts of the gyre remain low through-

Table 4. Comparison of phytoplankton dynamics and physiochemical parameters between WG (Stn KNOT) and AG (Stn P). $I_{0}$ : surface irradiance. Integrated values are for upper $100 \mathrm{~m}$ water column

\begin{tabular}{|c|c|c|}
\hline Parameter & KNOT & $\mathrm{P}$ \\
\hline Sea surface temperature $\left({ }^{\circ} \mathrm{C}\right)$ & 6.8 & 10.1 \\
\hline Surface water $\mathrm{NO}_{3}+\mathrm{NO}_{2}(\mu \mathrm{M})$ & 9.9 & 11.3 \\
\hline $\mathrm{SiO}_{2}(\mu \mathrm{M})$ & 1.7 & 18.7 \\
\hline $\mathrm{PO}_{4}(\mu \mathrm{M})$ & 1.14 & 1.21 \\
\hline $\mathrm{NH}_{4}(\mu \mathrm{M})$ & 0.65 & 0.15 \\
\hline Fe conc. $(\mathrm{nM})^{\mathrm{a}}$, surface & 0.05 & $<0.01$ \\
\hline $\begin{array}{r}\text { Fe conc. }(\mathrm{nM})^{\mathrm{a}}, \text { surface } \\
50 \mathrm{~m}\end{array}$ & 0.17 & 0.02 \\
\hline $100 \mathrm{~m}$ & 0.93 & 0.02 \\
\hline $1 \% I_{0}(\mathrm{~m}) \quad 57$ & 63 & \\
\hline Chlorophyll $a$, surface $\left(\mathrm{mg} \mathrm{m}^{-3}\right)$ & 0.38 & 0.28 \\
\hline Chlorophyll $a$, integrated $\left(\mathrm{mg} \mathrm{m}^{-2}\right)$ & 42.7 & 35.3 \\
\hline$F_{\mathrm{v}} / F_{\mathrm{m}} \mathrm{b}^{\mathrm{x}}$ & $0.3-0.5$ & $0.15-0.4$ \\
\hline Synechococcus $\left(10^{7}\right.$ cells cm $\left.{ }^{-2}\right)$ & 5.4 & 5.5 \\
\hline Eukaryotic ultraplankton $\left(10^{7}\right.$ cells $\left.\mathrm{cm}^{-2}\right)$ & 9.5 & 4.6 \\
\hline Syn C:Euk C & 1:15 & $1: 7$ \\
\hline Heterotrophic bacteria $\left(10^{9}\right.$ cells $\left.\mathrm{cm}^{-2}\right)$ & 6.6 & 7.8 \\
\hline Total phytoplankton carbon $\left(\mathrm{mg} \mathrm{C} \mathrm{m}^{-2}\right)$ & 2138 & 1766 \\
\hline$\%$ picophytoplankton carbon & 71 & 45 \\
\hline Bacterial C/autotrophic C & 0.38 & 0.54 \\
\hline \multirow{2}{*}{$\begin{array}{l}\text { Phytoplankton growth rate }\left(\mathrm{d}^{-1}\right)^{\mathrm{c}} \\
\text { Microzooplankton grazing rate }\left(\mathrm{d}^{-1}\right)^{\mathrm{c}}\end{array}$} & 0.28 & 0.20 \\
\hline & 0.42 & 0.13 \\
\hline \multicolumn{3}{|l|}{${ }^{\mathrm{a}} \mathrm{H}$. Obata pers. comm. } \\
\hline \multicolumn{3}{|l|}{${ }^{\mathrm{b}}$ See Suzuki et al. (2000) } \\
\hline \multicolumn{3}{|l|}{ c See Liu et al. (2001) } \\
\hline
\end{tabular}

out the year (e.g. Parsons \& Anderson 1970, Saino et al. 1979, Odate 1996, Shiomoto et al. 1998), although the lack of time-series observations in the WG hinders a comprehensive analysis of the phytoplankton annual cycle and its control mechanisms. Based on limited information, it appears that phytoplankton productivity in the WG is also Fe-limited (see Harrison et al. 1999). During our survey, the 2 gyres exhibited some similarities and differences in biogeochemical characteristics (Table 4). Concentrations of major nutrients were similar, but Stn P had higher silicate concentrations than Stn KNOT. Both stations had low chlorophyll a concentrations and picoplankton-dominated phytoplankton communities. Picoplankton mainly take up ammonium produced by micrograzers; this reduces their iron requirements, since no iron is required to assimilate ammonium into amino acids. The lower phytoplankton biomass, growth rate and productivity at Stn $\mathrm{P}$ are most likely a result of a more severe iron limitation there than that at Stn KNOT. The following evidence supports this conclusion: (1) The iron concentration at Stn P was totally depleted throughout the euphotic layer, but remained at around $0.05 \mathrm{nM}$ in the surface waters at Stn KNOT (Table 4 and H. Obata pers. comm.). (2) The physiological status of phytoplankton cells was healthier at Stn KNOT. Studies using the active fluorescence technique, which measures the quantum efficiencies $\left(F_{\mathrm{v}} / F_{\mathrm{m}}\right.$, variable/maximum fluorescence) and functional absorption crosssections of Phytosystem II $\left(\sigma_{\text {PSII }}\right)$, have shown that Fe limitation leads to suboptimal values of $F_{\mathrm{v}} / F_{\mathrm{m}}$ and thus reduces photosynthesis (Behrenfeld et al. 1996). Daily maximum and minimum values of $F_{\mathrm{v}} / F_{\mathrm{m}}$ measured by a fast repetition-rate fluorometer (FRRF) at Stn KNOT were 1.25 and 2 times higher than those at Stn P (Suzuki et al. 2000). (3) Phytoplankton growth and microzooplankton grazing rates measured with dilution experiments were higher at Stn KNOT than at Stn P (Liu et al. 2001).

Acknowledgements. We thank the chief scientist of the cruise, I. Koike, the captain and crew of the RV 'Hakuho Maru', and many other colleagues on board for their assistance in collecting the samples. We also thank H. Obata for providing the iron data. The authors are grateful to 3 anonymous referees for reviewing the manuscript and to Dr. S. W. A. Naqvi for commenting on an early draft. H.L. was supported by a postdoctoral fellowship from the Japan Society for the Promotion of Science (JSPS).

\section{LITERATURE CITED}

Ackleson SG, Spinrad RW (1988) Size and refractive index of individual marine particulates: a flow cytometric approach. Appl Optics 27:1270-1277

Agawin NSR, Duarte CM, Agustí S (2000) Nutrient and temperature control of the contribution of picoploankton to 
phytoplankton biomass and production. Limnol Oceanogr 45:591-600

Azam F, Fenchel T, Field JG, Gray JS, Meyer-Reil LA, Thingstad TF (1983) The ecological role of water-column microbes in the sea. Mar Ecol Prog Ser 10:257-263

Behrenfeld MJ, Bale AJ, Kolber AS, Aiken J, Falkowski PG (1996) Confirmation of iron limitation of phytoplankton photosynthesis in the equatorial Pacific Ocean. Nature 383:508-511

Binder BJ, Chisholm SW, Olson RJ, Frankel SL, Worden AZ (1996) Dynamics of picophytoplankton, ultraphytoplankton and bacteria in the central equatorial Pacific. DeepSea Res Part II 43:907-931

Blanchot J, André JM, Navarette C, Neveux J (1997) Picophytoplankton dynamics in the Equatorial Pacific: diel cycling from flow-cytometer observations. CR Acad Sci Ser III Sci Vie 320:925-931

Blanchot J, André JM, Navarette C, Neveux J, Radenac MH (2001) Picoplankton in the Equatorial Pacific: vertical distributions in the warm pool and in the high nutrient low chlorophyll conditions. Deep-Sea Res Part I 48:297-314

Booth BC (1988) Size classes and major taxonomic groups of phytoplankton at two locations in the subarctic Pacific Ocean in May and August, 1984. Mar Biol 97:275-286

Booth BC, Lewin J, Postel JR (1993) Temporal variation in the structure of autotrophic and heterotrophic communities in the subarctic Pacific. Prog Oceanogr 32:57-99

Boyd PW, Harrison PJ (1999) Phytoplankton dynamics in the NE subarctic Pacific. Deep-Sea Res Part II Top Stud Oceanogr 46:2405-2432

Boyd PW, Strom S, Whitney FA, Doherty S, Wen ME, Harrison PJ, Wong CS, Varela DE (1995a) The NE subarctic Pacific in winter. I. Biological standing stocks. Mar Ecol Prog Ser 128:11-24

Boyd PW, Whitney FA, Harrison PJ, Wong CS (1995b) The NE subarctic Pacific in winter. II. Biological rate processes. Mar Ecol Prog Ser 128:25-34

Brown SL, Landry MR, Barber RT, Campbell L, Garrison DL, Gowing MM (1999) Picophytoplankton dynamics and production in the Arabian Sea during the 1995 Southwest Monsoon. Deep-Sea Res Part II 46:1745-1768

Buck KR, Chavez FP, Campbell L (1996) Basin-wide distributions of living carbon components and the inverted trophic pyramid of the central gyre of the North Atlantic Ocean, summer 1993. Aquat Microb Ecol 10:283-298

Burkhill PH, Leakey RJG, Owens NJP, Mantoura RFC (1993) Synechococcus and its importance to the microbial foodweb of the northwestern Indian Ocean. Deep-Sea Res Part II 40:773-782

Campbell L, Vaulot D (1993) Photosynthetic picoplankton community structure in the subtropical North Pacific Ocean near Hawaii (station ALOHA). Deep-Sea Res Part I 40:2043-2060

Campbell L, Nolla HA, Vaulot D (1994) The importance of Prochlorococcus to community structure in the central North Pacific Ocean. Limnol Oceanogr 39:954-961

Campbell L, Landry MR, Nolla HA, Constantinou J, Brown SL, Liu H, Caron DA (1998) Response of microbial community structure to environmental forcing in the Arabian Sea. Deep-Sea Res Part II 45:2301-2326

Cho BC, Azam F (1990) Biogeochemical significance of bacterial biomass in the ocean's euphotic zone. Mar Ecol Prog Ser 63:253-259

Ducklow HW, Carlson CA (1992) Oceanic bacterial production. In: Marshall KC (ed) Advances in microbial ecology, Vol 12. Plenum Press, New York, p 113-181

Ducklow HW, Smith DC, Campbell L, Landry MR, Quinby
HL, Steward G, Azam F (2001) Heterotrophic bacterioplankton in the Arabian Sea: basinwide response to yearround high primary productivity. Deep-Sea Res Part II 48: 1303-1323

DuRand M (1995) Phytoplankton growth and diel variations in beam attenuation through individual cell analysis. PhD thesis, MIT-WHOI Joint Program in Oceanography

Fenchel T (1984) Suspended marine bacteria as a food source. In: Fasham MJ (ed) Flow of energy and materials in marine ecosystems. Plenum Press, New York, p 301-316

Fuhrman JA, Sleeter TD, Carlson CA, Proctor LM (1989) Dominance of bacterial biomass in the Sargasso Sea and its ecological implications. Mar Ecol Prog Ser 57:207-217

Fukuda R, Ogawa H, Nagata T, Koike I (1998) Direct determination of carbon and nitrogen contents of natural bacterial assemblages in marine environments. Appl Environ Microbiol 64:3352-3358

Garrison DL, Gowing MM, Hughes MP, Campbell L and 11 others (2000) Microbial food web structure in the Arabian Sea: a US JGOFS study. Deep-Sea Res Part II 47: 1387-1422

Harrison PJ, Boyd PW, Varela DE, Takeda S, Shiomoto A, Odate T (1999) Comparison of factors controlling phytoplankton productivity in the NE and NW subarctic Pacific gyres. Prog Oceanogr 43:205-234

Kirchman DL, Keil RG, Simon M, Welschmeyer NA (1993) Biomass and production of heterotrophic bacterioplankton in the oceanic subarctic Pacific. Deep-Sea Res Part I 40: 967-988

Lee S, Fuhrman JA (1987) Relationship between biovolume and biomass of naturally derived marine bacterioplankton. Appl Environ Microbiol 53:1298-1303

Li WKW (1995) Composition of ultraphytoplankton in the central North Atlantic. Mar Ecol Prog Ser 122:1-8

Li WKW, Subba Rao DVW, Harrison G, Smith JC, Cullen JJ, Irwin B, Platt T (1983) Autotrophic picoplankton in the tropical ocean. Science 219:292-295

Liu H, Bidigare RR, Laws E, Landry MR, Campbell L (1999) Cell cycle and physiological characteristics of Synechococcus (WH7803) in chemostat culture. Mar Ecol Prog Ser 189:17-25

Liu H, Suzuki K, Minami C, Saino T (2001) Phytoplankton growth and microzooplankton grazing in the subarctic North Pacific Ocean and Bering Sea during summer 1999. Deep-Sea Res Part I 49:363-375

Marie D, Partensky F, Jacquet S, Vaulot D (1997) Enumeration and cell cycle analysis of natural population of marine picoplankton by flow cytometry using the nucleic acid stain SYBR Green I. Appl Environ Microbiol 63:186-193

Martin JH, Fitzwater SE (1988) Iron deficiency limits phytoplankton growth in the north-east Pacific subarctic. Nature 331:341-343

Miller CB, Frost BW, Wheeler PA, Landry MR, Welschmeyer N, Powel TM (1991) Ecological dynamics in the subarctic Pacific, a possible iron-limited ecosystem. Limnol Oceanogr 36:1600-1615

Moore LR, Goericke R, Chisholm SW (1995) Comparative physiology of Synechococcus and Prochlorococcus: influence of light and temperature on growth, pigments, fluorescence and absorptive properties. Mar Ecol Prog Ser 116:259-275

Morel A (1991) Optics of marine particles and marine optics. NATO ASI Ser G Ecol Sci 27:141-188

Murphy LS, Haugen EM (1995) The distribution and abundance of phototrophic ultraplankton in the North Atlantic. Limnol Oceanogr 30:47-58

Obayashi Y, Tanoue E, Suzuki K, Handa N, Nojiri Y, Wong CS 
(2001) Spatial and temporal variabilities of phytoplankton community structure in the northern North Pacific as determined by phytoplankton pigments. Deep-Sea Res Part I 48:439-469

Odate T (1996) Abundance and size composition of the summer phytoplankton communities in the western North Pacific Ocean, the Bering Sea, and the Gulf of Alaska. J Oceanogr 52:335-351

Odate T, Maita Y (1988-1989) Regional variation in the size composition of phytoplankton communities in the western North Pacific Ocean, spring 1985. Biol Oceanogr 6:65-77

Parsons TR, Anderson GC (1970) Large scale studies of primary production in the North Pacific Ocean. Deep-Sea Res 17:765-776

Partensky F, Blanchot J, Vaulot D (1999) Differential distribution and ecology of Prochlorococcus and Synechococcus in oceanic waters: a review. Bull Inst Océanogr (Monaco) (numéro spécial) 19:457-475

Porter K, Feig YS (1980) The use of DAPI for identifying and counting aquatic microflora. Limnol Oceanogr 25:943-948

Raven JA (1998) The twelfth Tansley lecture. Small is beautiful: the picophytoplankton. Funct Ecol 12:503-513

Reckermann M, Veldhuis MJW (1997) Trophic interations between picophytoplankton and micro- and nanozooplankton in the western Arabian Sea during the NE monsoon 1993. Aquat Microb Ecol 12:263-273

Saino T, Miyazaki K, Hattori A (1979) Primary productivity in the Bering and Chukchi Seas and in the northern North Pacific in 1978 summer. Bull Plankton Soc Jpn 26:96-103

Shalapyonok A, Olson, RJ, Shalapyonok LS (2001) Arabian Sea phytoplankton during Southwest and Northeast Monsoons 1995: composition, size structure and biomass from individual cell properties measured by flow cytometry. Deep-Sea Res Part I 48:1231-1261

Sherr EB, Sherr BF (1987) High rates of consumption of bacteria by pelagic ciliates. Nature 325:710-711

Shiomoto A, Tadokoro K, Monaka K, Nanba M (1997) Productivity of picoplankton compared with that of larger phytoplankton in the subaractic region. J Plankton Res 19:907-916

Shiomoto A, Ishida Y, Tamaki M, Yamanaka Y (1998) Primary production and chlorophyll a in the northwestern Pacific Ocean in summer. J Geophys Res 103:24651-24661

Sosik HM, Chisholm SW, Olson RJ (1989) Chlorophyll fluorescence from single cells: interpretation of flow cytometric signals. Limnol Oceanogr 34:1749-1761

Editorial responsibility: Otto Kinne (Editor),

Oldendorf/Luhe, Germany
Suzuki K, Liu H, Minami C, Saino T (2000) Photosynthetic potential of phytoplankton in the subarctic Pacific as estimated by active fluorescence technique. Ocean Optics XV. (CD-ROM paper no. 1153) The Office of Naval Research, Ocean, Atmosphere, and Space S\&T Department, Arlington, VA

Suzuki K, Minami C, Liu H, Saino T (2002) Temporal and spatial patterns of chemotaxonomic algal pigments in the subarctic Pacific and the Bering Sea during summer 1999. Deep-Sea Res Part II (in press)

Suzuki R, Ishimaru T (1990) An improved method for the determination of phytoplankton chlorophyll using $\mathrm{N}, \mathrm{N}-$ dimethylformamide. J Oceanogr Soc Jpn 46:190-194

Taguchi S, Saito H, Kasai H, Kono T, Kawasaki Y (1992) Hydrography and spatial variability in the size distribution of phytoplankton along the Kurile Islands in the western subarctic Pacific Ocean. Fish Oceanogr 1:227-237

Taylor AH, Geider RJ, Glibert FJH (1997) Seasonal and latitudinal dependencies of phytoplankton carbon-to-chlorophyll a ratios: results of a modeling study. Mar Ecol Prog Ser 152:51-66

Varela DE, Harrison PJ (1999) Effect of ammonium on nitrate utilization by Emiliania huxleyi a coccolithophore from the northeastern Pacific. Mar Ecol Prog Ser 186:67-74

Vaulot D (1989) CYTOPC: processing software for flow cytometric data. Signal Noise 2:8

Vaulot D, Courties C, Partensky F (1989) A simple method to preserve oceanic phytoplankton for flow cytometric analysis. Cytometry 10: 629-635

Veldhuis MJW, Kraay GW, van Bleijswijk JD, Baars MA (1997) Seasonal and spatial variability in phytoplankton biomass, productivity and growth in the northwestern Indian Ocean: the southwest and northeast monsoon, 1992-1993. Deep-Sea Res 44:425-449

Welschmeyer NA, Strom SL, Goericke R, DiTuillio G, Belvin B, Peterson W (1993) Primary production in the subarctic Pacific Ocean: Project SUPER. Prog Oceanogr 32:101-135

Wong CS, Whitney FA, Iseki K, Page JS, Zeng J (1995) Analysis of trends in primary productivity and chlorophyll-a over two decades at Ocean Station $\mathrm{P}\left(50^{\circ} \mathrm{N}, 145^{\circ} \mathrm{W}\right)$ in the subarctic northeast Pacific Ocean. Can J Fish Aquat Sci 121:107-117

Zubkov MV, Sleigh MA, Tarran GA, Burkill PH, Leakey RJG (1998) Picoplanktonic community structure on an Atlantic transect from $50^{\circ} \mathrm{N}$ to $50^{\circ} \mathrm{S}$. Deep-Sea Res Part I 45 : 1339-1355

Submitted: June 25, 2001; Accepted: November 27, 2001

Proofs received from author(s): July 4, 2002 